\title{
PSIKOLOGI KEBAHAGIAAN DENGAN PENDEKATAN NASH
}

\author{
Muhammad Tahir.A. \\ Institut Agama Islam Negeri Manado \\ E-mail: muhammad.tahir@iain-manado.ac.id
}

\begin{abstract}
The psychology of happiness with the nash approach aims to examine two things namely disaster and suffering whose purpose is to live happily. It is against this background that throughout human life only to achieve happiness. This type of research is a literature study with a nash approach. By using library data that is related to the discussion of psychology or discussion about happiness. The main reference in enriching the discussion on the psychology of happiness refers to the Qur'an and the Hadith. Based on the study of the text, it was found that the commands and prohibitions of religion are essentially aimed at making humans happy in the world and the hereafter. Therefore, humans must choose to live happily according to religious orders.
\end{abstract}

Keywords: psychology, happiness, disaster, suffering.

\begin{abstract}
ABSTRAK
Psikologi kebahagiaan dengan pendekatan nash bertujuan untuk mengkaji dua hal yakni musibah dan penderitaan yang tujuannya untuk hidup berbahagia. Hal tersebut dilatar belakangi bahwa sepanjang hidup manusia hanya untuk mencapai kebahagiaan. Jenis penelitian yang digunakan adalah studi literatur dengan pendekatan nash. Dengan menggunakan data-data pustaka yang ada kaitannya dengan pembahasan psikologi ataupun pembahasan tentang kebahagiaan. Refrensi utama dalam memperkaya pembahasan tentang psikologi kebahagiaan merujuk kepada nash al-Qur'an dan Hadis. Berdasarkan kajian nash, didapati bahwa perintah dan larangan agama pada hakikatnya bertujuan agar manusia senantiasa berbahagia di dunia maupun di akhirat. Oleh karena itu, manusia wajib memilih untuk hidup bahagia sebagaimana perintah agama.
\end{abstract}

Kata kunci: psikologi, kebahagiaan, musibah, penderitaan.

\section{PENDAHULUAN}

Psikologi (Jalaluddin, 2016) diartikan secara umum, untuk mempelajari gejala-gejala kejiwaan manusia yang berkaitan dengan pikiran (cognisi), perasaan (emosition), dan kehendak (conasi).

Psikologi telah banyak melahirkan teori tentang manusia, ada empat pendekatan dalam psikologi yakni psikoanalisis, behaviorisme, psikologi kognitif dan psikologi humanistis.
Psikoanalisis menganggap manusia berkeinginan, psikologi kognitif manusia dianggap berpikir, psikologi behaviorisme manusia ibarat mesin sementara psikologi humanisme menganggap manusia bermain/manusia sosial (Rakhmat, 2018)

$$
\text { Psikologi mengalami perkembangan }
$$
dan menjadi kajian yang diminati sebab ia berusaha mengungkap kepribadianmanusia, tidak berlebihan bila psikologi dapat 
diartikan ilmu untuk mengenal diri sendiri lebih dalam

Ada beberapa nama yang dilekatkan pada psikologi, misalnya psikologi pendidikan, psikologi klinis, psikologi anak, psikologi agama, psikologi abnormal. Psikologi pendidikan digunakan untuk mendeteksi perkembangan anak didik, psikologi klinis dijadikan media untuk mengobati penyakit mental pasien umumnya dilakukan oleh dokter, psikologi agama bertujuan untuk mengkaji kejiwaan, tingkah laku orang-orang yang beragama, lalu kenapa belum, tidak ada psikologi kebahagiaan? Psikologi kebahagiaan bertujuan untuk mengkaji komponenkomponen yang dapat membahagiakan serta yang dapat membuatnya menderita.

Baik ilmu kedokteran, psikologi, maupun agama ketiganya memiliki kedekatan dalam hal; semuanya ingin membantu dan melayani manusia agar hidup sehat dan bahagia. Ilmu kedokteran mengkaji manusia dari segi struktur dan kinerja organ-organ tubuh serta jaringan sel agar bisa memabantu meluruskan kembali jika terjadi kerusakan dan penyimpangan demi kesehatan manusia.

Lalu ilmu psikologi memilih mental dan kejiwaan untuk dikaji. Lebih dari itu, psikologi juga mengkaji potensi-potensi yang terpendam pada diri manusia untuk dibantu agar tumbuh dan teraktualisasikan dalam kehidupan (Hidayat, 2006).

Jika ilmu kedokteran mendeteksi penyakit luar (badan) manusia, maka ilmu psikologi mendeteksi penyakit dalam (jiwa) manusia. Keduanya menawarkan penawar atas segala masalah yang dihadapi manusia demi mencapai kebahagiaan.

Lalu dimana posisi agama? Agama membicarakan penyakit luar (badan) maupun penyakit jiwa. Jauh sebelum ilmu kedokteran ditemukan begitu juga dengan ilmu psikologi, agama telah membicarakan keduanya.

Agama mengajarkan untuk menjaga kebersihan badan dan jiwa. Untuk menjaga kesehatan badan maka diajarkan untuk senantiasa menjaga kebersihan badan, dalam fiqih disebut bab al-thaharah (tata cara mensucikan badan). Sementara untuk membersihkan jiwa, dalam tasawuf disebut tazkiyah al-nafs (tata cara mensucikan jiwa). Inilah makna al-Qur'an dalam surah al-Baqarah ayat 222 innallaha yuhibbut thawwabina wa yuhibbul muthathahhirina. Dalam al-Qur'an surah al-A'raf ayat 31 Allah menggandengkan makan-minun dengan sifat berlebihan (boros). Makanminum berlebihan akan meruskan kesehatan badan, sementara berlebihan (boros) adalah penyakit jiwa.

Al-Qur'an ini menegaskan bahwa kesucian badan-jiwa dari kotoran adalah 
satu paket, tidak bisa dipisahkan satu dengan lainnya. Jika badan kotor akan mempengaruhi jiwa, sebaliknya, bila jiwa kotor akan merusak kesehatan badan. Dalam keadaan ini, manusia semakin jauh dari kebahagiaan yang didambanya. Malah, mungkin sekali dia mengira sedang membahagiakan dirinya, tapi sebenarnya dia sedang menyakiti dan menyiksanya (Kazhim, 2008). Maka penting untuk mengenal sesuatu yang dapat mengotori badan begitu juga dengan jiwa serta cara mengobatinya.

Ilmu kedokteran dan ilmu psikologi sangat berjasa terhadap agama sebab melalui keduanya (kedokteran-psikologi) ajaran-ajaran agama yang sulit diterima, seiring perjalanan waktu ternyata sangat sesuai dengan ilmu kedokteran maupun ilmu psikologi.

$$
\text { Larangan agama untuk }
$$
mengkonsumsi narkoba, melalui keterangan ilmu kedokteran maka larangan tersebut diterima secara rasional oleh orang yang dulu menolaknya.

Setiap larangan agama pada hakikatnya mengandung bahaya, sementara setiap perintah agama pada hakikatnya mengandung manfaat bagi manusia tersebut. Ilmu kedokteran menerangkan perintah-larangan agama secara ilmiah, secara rasional sehingga dapat diterima, demikian juga dengan ilmu psikologi.
Agama melarang kita untuk memelihara dendam, sebab dendam bukan hanya menghilangkan pahala dalam pandangan agama, tetapi dalam tinjauan psikologi dendam akan menyebabkan penyakit badan dan jiwa sehingga menghilangkan kebahagiaan manusia itu sendiri. Memelihara dendam berarti larut dalam penderitaan, sementara memaafkan berarti larut dalam kebahagiaan. penderitaan dan kebahagiaan adalah pilihan.

Artikel ini hadir sebagai sumbangsih pemikiran terhadap psikologi kebahagiaan dengan pendekatan nash. Pendekatan nash yang dimaksud adalah bersumber dari alQur'an dan Sunnah.

\section{PEMBAHASAN}

Dalam buku Meraih Kebahagiaan ia mengisahkan tentang seorang ustadz, sore itu, ia datang lagi. Masih berpakaian rapi dan menjinjing tas Echolac. Wajahnya masih kuyu. Garis-garis ketuaan memantulkan kelelahan yang berkepanjangan. Kantong-kantong kecil di bawah matanya tampak seperti merekam deritanya yang tanpa henti.

"Ustaz", ia memulai pembicaraan setelah menarik nafas panjang. "saya sudah berpuasa senin-kamis dengan setia. Hampir setiap malam saya salat tahajud. Saya sampaikan doa saya; kadang-kadang 
dengan air mata yang berlinang. Saya hanya bermohon agar saya tidak bergantung pada obat. Itu saja!”

Kawanku itu, "mantan" mubalig. Sebetulnya lebih tepat, ia mantankan oleh jamaahnya. Di tengah-tengah aktivitasnya sebagai mubalig muda, ia terlibat dalam tindakan "kekerasan" yang melawan pemerintah. Kawan-kawannya ditangkap. Ia selamat, ia tidak masuk penjara, namun penjara masuk pada dirinya. Ia dikejar-kejar ketakutan. Ia jatuh sakit, dirawat di rumah sakit jiwa selama berbulan-bulan.

Karena sakitnya, ia dipecat dari pekerjaan tetapnya. Ia juga dijauhi oleh para jamaahnya. Setelah sembuh, untuk memenuhi kebutuhan hidupnya, ia berusaha berjualan buku dari kantor ke kantor. Untuk mempertahankan kesehatan mentalnya, ia harus minum obat secara teratur.

"Saya tidak sanggup lagi memikul derita ini. Kasihan anak-anak dan istri saya. Mengapa Tuhan menghukum saya lebih dari kemampuan saya. Bukankah dalam al-Qur'an, Allah swt berfirmanAllah tidak membebani setiap diri lebih dari kemampuannya? Jika ini dibebankan kepada saya karena dosa-dosa saya, bukankah saya telah terus-menerus beristighfar. Saya telah berusaha menjalankan agama semampu saya. Mengapa saya masih juga menderita? Katanya, agama diturukan untuk membawa kita kepada kebahagiaan dunia dan akhirat Bila Kebahagiaan akhirat tidak bisa diketahui. Paling tidak kita harus melihatnya dari kebahagiaan di dunia ini."(Rakhmat, 2006).

Kisah di atas bisa jadi mewakili apa yang kita alami saat ini. Ia menderita dalam hidupnya sehingga derita itu tidak sanggup ia jalani, hingga akhirnya ia mempertanyakan takdir Allah swt.

\section{A. Musibah dan Penderitaan}

Merujuk kepada al-Qur'an bahwa Allah swt akan menguji hambanya dengan rasa takut, rasa lapar, kekurangan harta, kematian dan kekurangan buah-buahan (Qs.2:155). Manusia sudah ditakdirkan akan merasakan itu semua tanpa peduli agama, mazhab, suku, rasa mereka. Musibah dalam bahasa agama adalah ketetapan Allah yang tidak bisa ditolak ataupun dilawan, namun menderita akibat musibah yang datang kepada kita akan direspon secara berbeda. Ada yang menderita (umumnya demikian) namun ada sebagian dari mereka yang tertimpa musibah justru berbahagia.

Kata para filusuf, musibah adalah realitas objektif. Sementara penderitaan adalah realitas subjektif. Musibah datang dari luar, sementara penderitaan adalah pictures in our head. Jadi, penderitaan dan kebahagiaan tergantung pada pilihan 
manusia. Menderita atau bahagia atas musibah sangat tergantung pada sikap manusia dalam memaknai musibah tersebut. Seringkali penderitaan punya makna psikologis. Manusia bebas memilih jalan hidup (menderita atau bahagia) dengan menggunakan fasilitas yang dimiliki, terutama emosi, pikiran, hati, dan fisiknya (Hidayat, 2006).

Segala sesuatu itu dari tuhan itu indah, karena Dia Sang Mahaindah. Semuanya sempurna, karena Yang Mahasempurna yang telah menghadirkannya. Itulah ketentuan. Adapun kadarnya, bentuknya, bagaimana ia sampai pada kita, di sinilah letak usaha kita. Di sini kerja keras kita (Rakhmat, 2015).

Kebahagiaan tidak sama dengan kumpulan kenikmatan (pleasure). Mungkin saja hidup seseorang dipenuhi kenikmatan, tetapi dia tak bahagia. Kebahagiaan juga bukan berarti ketiadaan kesulitan dan penderitaan. Karena, boleh jadi penderitaan datang silih berganti, tetapi kesemuannya itu tidak merusak kebahagiaan. inilah yang disebut sebagai underlying happiness (kebahagiaan yang senantiasa lestari) dalam hidup kita (Baqir, 2015).

Kebahagiaan

memberikan kedamaian dan ketentaraman dalam hati yang lebih lestari. Dalam bahasa al-Qur'an disebut al-Baqiyah al-shalihat (kebaikan- kebaikan yang senantiasa mewujud) lihat Qs. al-Kahfi/18:46.

Kesenangan tidak sama dengan kebahagiaan. kesenangan berkaitan dengan hal-hal yang material (jasmani) yang bersifat jangka pendek, sedangkan kebahagiaan adalah keadaan jiwa (rohani) yang bersifat jangka panjang. Dalam bahasa Mulla Sadra, kebahagiaan adalah wujud (eksistensi) yang tetap, sedangkan kesenangan adalah mahiyah (esensi) yang senantiasa berubah. Manusia tidak anti terhadap kesenangan sebab itu sifat alamiah manusia, namun kesenangan tidak boleh menjadikan manusia untuk tidak meraih kebahagiaan (rohani) (Subhani, 2012).

Banyak orang yang mengejar kebahagiaan tetapi sebenarnya yang ia dapatkan hanyalah kesenangan, masalahnya karena ia tidak bisa membedakan antara kebahagiaan dan kesenangan.

\section{B. Tujuan Hidup adalah Bahagia}

KH. Husain Muhammad (Haidar, 2017) mengutip ungkapan hikmah bahwa:

"Tujuan kita satu yaitu kebahagiaan, tetapi jalan kita (meraih kebahagiaan) berbedabeda".

Kebahagiaan makhluk hidup akan tercipta jika ada keserasian dan keharmonisan antara makhluk itu dengan lingkungan yang mengelilinginya. Manusia adalah makhluk hidup yang juga bagian dari hukum universal yang berlaku di alam 
ini. Jadi, agar manusia tetap hidup dalam kebahagiaan, dia harus sejalan dan searah dengan lingkungannya dan segala faktor yang mengelilinginya (Muthahhari, 1996). Manusia terikat dengan alam yang lainnya, sebagaimana alam lainpun terikat dengan manusia. Ekosistem mengharuskan kita untuk saling mengisi demi kebahagiaan bersama.

Mengutip dalam buku meraih kebahagiaan (Rakhmat, 2006), Socrates menyebutkan kunci kebahagiaan adalah "mengikuti alam". Para muridnya kemudian menafsirkannya dengan berbagai macam penafsiran. Aristippus memahaminya dengan memenuhi tuntutan kesenangan jasmaniah. Kaum stoik menafsirkan dengan menekan kesenangan jasmaniah dan memuaskan akal kita. Menurut Aristoteles menjalankan "fitrah" kemanusiaan kita. Menurut Plato berfungsinya seluruh bagian jiwa secara harmonis. Anda bahagia, jika dalam pandangan anda tidak ada bedanya hidup dan mati, penjara dan istana, miskin dan kaya, racun dan madu (Rakhmat, 2006).

Mazhab Cynis memiliki prinsip untuk mencapai kebahagiaan dengan membebaskan jiwa dari keterikatan pada “daging/materi”. Ia berkata, “aku tidak memiliki agar aku tidak dimiliki. Kebahagiaan adalah kebebasan dari segala ikatan yang terbatas sambil terikat pada yang tak terbatas. Dalam bahasa Imam Ali bin Abi Thalib kw berkata manusia yang paling bahagia adalah orang yang meninggalkan kelezatan yang sementara untuk kelezatan yang abadi (as'ad al-nās man taraka ladzatan fäiyatan liladzatin bāqiyatin).

Jalaluddin Rumi mengisahkan ketika Abu Yazid ditanya oleh Allah swt, "Hai Abu Yazid, apa yang engkau inginkan?" Abu Yazid menjawab, "aku ingin agar aku tidak menginginkan.”

Segala derita dan gelisah akan muncul saat kau menginginkan sesuatu tetapi kau sulit mendapatkannya. Sementara ketika kau tidak menginginkan, maka tidak ada derita di sana yang ada hanyalah kebahagiaan semata (Rumi, 2017).

Para filusuf, kaum sufi, serta psikolog pada hakikatnya melakukan kajian terhadap diri manusia hanya untuk mengungkap agar mereka tahu agar senantiasa bahagia. Tujuan hidup hanyalah satu yakni kebahagiaan, akan tetapi sarana, media untuk mencapainya berbeba-beda.

Mari kita lihat konsep kebahagiaan dengan pendekatan nash baik al-Qur'an maupun sunnah.

Menurut Jalaluddin Rakhmat kata yang dapat menggambarkan kebahagiaan adalah aflaha. Di empat ayat al-Qur'an yakni Qs. 20:64, Qs. 23:1, Qs.87:14, Qs. 91:9. Kata itu selalu didahului kata 
penegas/taukid, qad (sungguh) sehingga berbunyi qad aflaha 'sungguh telah berbahagia. Kata aflaha adalah derivasi dari akar kata falāh (Rakhmat, 2010).

Kamus-kamus bahasa arab klasik merinci makna falāh sebagai berikut: kemakmuran, keberhasilan; pencapaian apa yang kita inginkan atau kita cari, bahagia atau baik; terus-menerus dalam keadaan baik; menikmati ketentraman, kenyamanan hidup atau kehidupan yang penuh berkah; keabadian, kelestarian, terus-menerus, keberlanjutan (Rakhmat, 2010).

Makna dari kata falah sekaligus menjadi ciri-ciri orang yang berbahagia. Kebahagiaan dipenuhi dengan kemakmuran, keberhasilan, pencapaian, penuh ketentraman, hidup penuh berkah, kebaikan yang lestari atau terus menerus. Oleh karena itu, kesenangan berbeda dengan kebahagiaan, kesenangan sifatnya sementara, kebahagiaan sifat abadi, lestari, terus-menerus.

Dalam al-Qur'an selain kata aflaha, juga digunakan kata tuflihūna, kata tersebut disebut 11 kali dalam al-Qur'an dan selalu didahului dengan kata la'allakum. Makna la'allakum tuflihūna 'semoga/agar kalian berbahagia. Ayat-ayat yang berujung pada la'allakum tuflihūna dapat dijabarkan sebagai berikut.

1. Bertakwalah kepada Allah agar kalian berbahagia (Qs.2:189)
2. Wahai orang-orang beriman! Janganlah kalian memakan riba yang berlipat-lipat. Bertakwalah kepada Allah agar kalian berbahagia (Qs.3:130

3. Wahai orang-orang beriman! Bersabarlah dan saling menyabarkan, serta perkuat persatuanmu agar kalian berbahagia (Qs.3:200)

4. Wahai orang-orang beriman! Bertakwalah kepada Allah. Carilah jalan untuk mendekatkan diri kepada-Nya. Berjuanglah di jalan Allah agar kalian berbahagia (Qs.5:35)

5. Wahai orang-orang beriman! Sesungguhnya minuman keras, perjudian, undian, dan taruhan adalah kotoran dari perbuatan setan. Jauhilah, agar kalian berbahagia (Qs.5:90)

6. Katakanlah: tidak sama antara keburukan dan kebaikan, walaupun banyaknya keburukan memesona kalian. Bertakwalah kepada Allah agar kalian berbahagia (Qs.5:100)

7. Kenanglah anugerah-anugerah Allah agar kalian berbahagia (Qs.7:69)

8. Wahai orang-orang beriman! Jika kalian berjumpa dengan sekelompok musuh, teguhkanlah 
hatimu. Banyaklah berzikir kepada Allah agar kalian berbahagia (Qs.8:45)

9. Wahai orang-orang beriman! Rukuklah dan sujudlah. Beribadahlah kepada Tuhanmu, serta berbuatlah kebaikan agar kalian berbahagia (Qs.22:73)

10. Bertobatlah kalian kepada Allah seluruhnya, wahai orang-orang beriman, agar kalian berbahagia (Qs.24:31)

11. Apabila selesai melaksanakan shalat, menyebarlah di muka bumi. Carilah karunia Allah dan perbanyaklah berzikir kepada Allah agar kalian berbahagia (Qs.62:10). Dari sebelas ayat dikutip menunjukkan bahwa tujuan akhir dari perintah-larangan Allah swt kepada hambaNya agar kita semua berbahagia. Karena itu, memilih untuk berbahagia adalah bagian dari perintah agama. Maka memilih untuk senantiasa berbahagia adalah ibadah.

\section{PENUTUP}

Psikologi hadir untuk mengkaji gejala-gejala mental, jiwa manusia. Bila ilmu kedokteran bertujuan mendeteksi penyakit badan maka psikologi bertujuan untuk mendeteksi penyakit jiwa.

Dalam ajaran Islam baik penyakit badan maupun penyakit jiwa keduanya menjadi perhatian dalam agama. Oleh karena itu, baik ilmu kedokteran maupun ilmu psikologi keduanya dapat dijadikan alat untuk menerangkan ajaran-ajaran agama yang sulit dipahami.

Psikologi kebahagiaan dengan pendekatan nash bertujuan untuk mengkaji komponen-komponen yang dapat mengantarkan manusia untuk meraih kebahagiaan bukan hanya di dunia tetapi juga di akhirat.

Kebahagian dan kesenangan adalah dua hanya yang berbeda. Kesenangan sifatnya material yang bersifat pendek, sementara kebahagiaan lebih bersifat psikologis-spiritual dan bersifat abadi. Kebahagiaan itu eksistensi (wujud), kesenangan itu esensial (mahiyah).

Kunci kebahagiaan pada persoalan memaknai suatu musibah. Musibah itu takdir yang tak dapat ditolak, namun merespon musibah manusia berbeda-beda. Tidak selamanya musibah mendatangkan penderitaan, justru terkadang musibah mendatangkan kebahagiaan. musibah itu takdir, tetapi bahagia atau menderita terhadap musibah sangat tergantung pada pilihan manusia.

Perintah-larangan agama pada hakikatnya mengandung manfaat-mudharat. Perintah-larangan itu dihadirkan agar manusia senantiasa berbahagia baik di dunia maupun di akhirat. 
Kajian khusus tentang psikologi, psikologi pendidikan, agama, klinis, abnormal, mungkin sudah saatnya melakukan kajian psikologi kebahagiaan, mengingat bahwa tujuan hidup kita di dunia agar kita berbahagia menjalani kehidupan di dunia ini begitu juga kelak di hari akhirat. Bukankah menjadi aneh bila tujuan hidup agar kita berbahagia, namun media untuk mencapai kebahagiaan tidak menjadi kajian tersendiri, khususnya dalam kajian psikologi. Semoga tulisan yang sederhana ini, dapat menjadi pintu awal atau menjadi pemicu bagi para akademisi untuk melakukan kajian tentang kebahagiaan dan memilih untuk senantiasa berbahagia.

\section{DAFTAR PUSTAKA}

Baqir, Haidar. (2015). Risalah Cinta dan Kebahagiaan. Jakarta Selatan: Mizan.

Baqir, Haidar. (2017). Islam Tuhan, Islam Manusia. Bandung: Mizan.

Hidayat, Kamaruddin. (2006). Psikologi Beragama Menjadikan Hidup Lebih Nyaman dan Santun. Jakarta Selatan: Hikmah.

Hidayat, Kamaruddin. (2006). Psikologi Kematian Mengubah Ketakutan
Menjadi Optimisme. Bandung: Mizan.

Hidayat, Kamaruddin. (2009). Berdamai Dengan Kematian. Jakarta Selatan: Hikmah.

Jalaluddin. (2016). Psikologi Agama: Memahami Perilaku dengan Mengaplikasikan Prinsip-Prinsip Psikologi. Jakarta: Rajawali Press.

Kazhim, Musa. (2008). The Secret of Your Spiritual DNA Mengelola Fitrah untuk Kesuksesan dan Kemuliaan Hidup. Jakarta Selatan: Hikmah.

Muthahhari, Murtadha. (1996). Jejak-Jejak Ruhani (Ahmad Subandi, Penerjemah). Bandung: Pustaka Hidayah.

Rakhmat, Jalaluddin. (2018). Psikologi Komunikasi, Cetakan Pertama Edisi Revisi. Bandung: Simbiosa Rekatama Media.

Rakhmat, Jalaluddin. (2006). Meraih Kebahagiaan. Bandung: Simbiosa Rekatama Media.

Rakhmat, Jalaluddin. (2010). Tafsir Kebahagiaan Pesan al-Qur'an Menyikapi Kesulitan Hidup. Jakarta: PT. Serambi Ilmu Semesta.

Rakhmat, Miftah F. (2015). Duabelas, Empatbelas Kumpulan Tulisan dan Lepas. Bandung: Satuempatbelas.

Rumi, Jalaluddin. (2017). Kitab Fihi Ma Fihi. Jakarta Selatan: Zaman.

Subhani, Ayatullah Ja'far. (2012). Keluar dari Kemelut menuju Kebahagiaan: Pemuda, Agama, dan Serangan Budaya (M. Ilyas, Penerjemah). Yogyakarta: RausyanFikr Institute. 